\title{
O Tribunal de Contas e seu Funcionamento
}

35.076

\section{Carlindo Hugueney}

\begin{abstract}
A
cada hora estamos vendo repetido, pelas mais autorizadas figuras da administração pública, que o Tribunal de Contas embaraça a administração e não poucas enteridem que melhor seria extinguí-lo.

Quem declara que o Tribunal de Contas cria entraves ao funcionamento da administração está, sem sombra de dúvida, dizendo uma verdade cristalina, pôsto que, conforme no-lo adverte ERIC WHITE, em suas aulas do Curso de Organização e Administração de Escritório (Office management), todo órgão de contrôle dificulta o funcionamento do serviço. Portanto, afirmar que o Tribunal de Contas embaraça o funcionamento da máquina burocrática não é novidade, como novidade não seria, também, dizer que o contrôle judicial dos atos administrativos também tolhe a administração, pois, se êle não existisse, não haveria peia que cerceasse as atividades do Poder Executivo.
\end{abstract}

Ninguém, contudo, contesta a imprescindibilidade do contrôle judicial que é uma necessidade indeclinável na organização dos podêres do Estado para garantia dos direitos individuais.

Ora, quando em 1215 os barões impuseram a João Sem Terra a assinatura da Magna Carta que, entre outros fatos, criou embaraços ao poder do monarca de lançar tributos, foi um primeiro passo, completado pela segunda restrição, imposta ao dirigente, de prestar contas ao povo daquilo que arrecadou.

Assim, a atividade do Tribunal de Contas provém da gênese da organização dos podêres do Estado, e ninguém, em sã consciência, poderá sustentar não ser ela necessária, mormente num país como o nosso, onde a educação cívica ainda não permite, a muito homem público, diferençar seu patrimônio particular daquele que êle gere em nome do povo.

Portanto, embora se reconheça que a atividade do órgão de contrôle cria embaraços, não se poderá concluir que ela deva cessar, porque fazê-lo seria regredir ao primitivismo.

Para o funcionamento de um bom sistema de contrôle, do ponto de vista da organização científica do trabalho, deve-se ter em vista, entre outros, os seguintes princípios:

$\left.1^{\circ}\right)$ reduzir-se ao mínimo o entrave à boa marcha do serviço controlado;

2.) evidenciar-se, pelos resultados obtidos, que as vantagens superam as desvantagens acarretadas no funcionamento do serviço. 
Quanto ao primeiro aspecto, data venia, a esta altura seria desnecessário examiná-lo, eis que os podêres públicos pràticamente já resolveram a questão, sem se deterem mais a fundo na análise do problema da vantagem ou desvantagem do sistema.

Com efeito, em que pese a circunstância de dispor a lei que, quando não fôr dito o contrário, o registro da despesa pelo Tribunal de Contas será prévio (Lei 830-49, art. 58), é tal o número de exceções que estas passaram a ser a regra.

Ora, se o exame da despesa é feito a posteriori, evidentemente que já chegou ao mínimo o entrave à administração para dispor dos dinheiros públicos.

Quanto aos resultados obtidos, é mister ressaltar ficarem muito aquém do que é lícito desejar. Isso resulta principalmente da modificação introduzida, como passaremos a demonstrar.

Realmente, o Código de Contabilidade Pública foi elaborado e a organização do Tribunal de Contas foi feita atentos ao sistema que preponderava na época: registro prévio.

Se a despesa antes de ser realizada dependia de exame pelo Tribunal e a recusa de registro importava em veto, não havia, é bem de ver, a necessidade de o Código dișciplinar o regime penal dos responsáveis pela má aplicação dos dinheiros públicos, pois que ela ficaria afastada com o regime de exame a priori.

Subverteu-se, entretanto, completamente o sistema, passando-se, de um modo geral, como se disse, a examinar as ordens de pagamento a posteriori sem que, contudo, se lembrasse o legislador de prescrever um eficiente sistema de sanções para aquêles que transgridem as normas legais.

Assim, está adstrito o Tribunal, em infrações das normas, a aplicar a multa prevista no art. 40 do Código (Cr\$ 200,00 a $\mathrm{Cr} \$ 10.000,00$ ); ou a representar ao Executivo contra a infração (art. 63 da Lei 830-49); ou a responsabilizar $Q$ ordenador da despesa, em certas conjunturas, pela totalidade do gasto.

Nenhuma dessas medidas atende, contudo, à realidade dos fatos.

Com efeito, aplicar, hoje em dia, multas de $\operatorname{Cr} \$ 200,00$ a $\operatorname{Cr} \$ 10.000,00$ é uma medida que se traduz, apenas, em sanção moral, perfeitamente dispensável para os bons administradores, que delas não precisam, e platônica para os maus que se locupletam com a coisa pública e que, portanto, não teriam capacidade moral para sentir punição dessa natureza.

No mesmo passo, parece-me extravagante que, cabendo ao Tribunal de Contas controlar a legalidade dos gastos do Executivo, quando há infração, tenha o órgão de contrôle de representar ao próprio infrator... Seria a medida tão platônica como a anterior, desde que houvesse interêsse do controlado em violar a norma. Além do mais, não há sanção reparatória compatível a aplicar-se ao responsável direto pela infração, nem àquele que deixou de submeter o ato a exame do Tribunal.

Não existe, ainda, nas hipóteses em que o Tribunal pode impor aos responsáveis a obrigação de repor a quantia gasta, justiça na sanção a ser aplicada. 
Com efeito, suponhamos que o responsável mandasse fazer uma obra no valor de um bilhão de cruzeiros e prescindisse de formalidade legal, como seja, concorrência, entregando o serviço a um amigo seu. Vindo o processo a exame do Tribunal de Contas, sob a forma de tomada de contas, o Tribunal terá sòmente duas alternativas: ou acha que está regular o que o responsável fêz e lhe dá quitação, ou então o condena a restituir o valor total da obra, um bilhão. Não há meio têrmo, oito ou oitenta.

Assim, não traz a lei um sistema adequado de sanções, o que se traduz em tornar pouco eficiente o sistema.

Por essa forma, o contrôle dificulta o bom administrador, tolhendo-lhe movimentos, ao passo que para o mau aplicador dos dinheiros públicos não se prevê na lei sanções compatíveis com a falta. Torna-se, assim, o mesmo desvantajoso sob o aspecto da eficiência e justificado, de um modo geral, tão sòmente pelo receio que impõe sua presença.

Por outro lado, no regime do registro prévio, pode o Tribunal de Contas ser um órgão estático, pôsto que, sem que a despesa venha a sua apreciação não se realiza. O mesmo, contudo, não ocorre nas outras hipóteses.

Examinado o panorama do país a partir da vigência do Código de Contabilidade, o que se verifica?

Houve, é bem de ver, transformação quase que radical: passou-se para o sistema de registro a posteriori, proliferou o de tomada de contas e vingou o sistema de "fundos" de constitucionalidade discutível. Por outro lado, a administração pública, de caráter centralizado, transformou-se inteiramente, criando-se inúmeros órgãos autárquicos, sociedades de economia mista e avança cada vez mais para o campo da economia privada, instituindo órgãos cujas personalidades jurídicas jazem no terreno da controvérsia.

O funcionamento do Tribunal de Contas, entretanto, continuou adstrito pràticamente às mesmas regras que tinha no sistema do registro prévio.

Ora, quando tudo evolui, aquilo que fica estático está evidentemente regredindo. E' a situação presente.

Observe-se, ainda, que, como constantemente tem salientado o próprio Tribunal, há fato deveras contristador no que tange ao contrôle que exerce: assustadora percentagem dos gastos públicos, cêrca de $90 \%$, nem sequer vem a sua apreciação.

Isso tem sua maior causa, evidentemente, naquilo que acabamos de expor: permanecendo o Tribunal adstrito ao critério, próprio do registro prévio, de aguardar que as despesas públicas venham a seu exame e como estas, de um modo geral, não dependem dessa formalidade para serem realizadas, vai ocorrendo o inevitável: cada vez mais diminui o ritmo da remessa das contas para seu exame.

Tudo indica, portanto, a conveniência de ser feito o reexame da atuação do Tribunal para adequá-la à situação presente, o que pode ser traduzido na máxima, citada pelo Sr. Ministro JoÃo LYRA FILHO, em seu excelente trabalho $\mathrm{Da}$ descentralização funcional dos Tribunais de Contas: "Uma 
vez que a atividade do Estado se desdobra através de múltiplas atividades, o Tribunal de Contas deve seguí-las para que possa atuar". (1)

Para a fórmula várias são as soluções que se apresentam, entre as quais, o I Congresso dos Tribunais de Contas do Brasil nos ofereceu algumas sugestốes, como sejam: "contrôle concomitante, diário, pari-passu, das autarquias", da autoria do Tribunal de Contas do Rio Grande do Sul; exame in loco nas tomadas de contas, usado por São Paulo; além das várias fórmulas aventadas pelo ilustrado Ministro JoÃo LYRA FILHo (obra citada).

Certo é que êste é problema, que se volve ao legislador ao se defrontar com a questão, e que não cabe ser analisado aqui, nestas rápidas considerações.

E' a matéria que só pode ser aplainada e resolvida pelo Congresso $\mathrm{Na}$ cional já que o Poder Constituinte erigiu o Tribunal de Contas em órgão auxiliar daquele Poder na fiscalização da administração financeira.

Fica-lhe, pois, nesta assentada, apenas a sugestão no sentido de que, para haver contrôle eficiente por parte do Tribunal de Contas, é indispensável, quando nada:

1. ${ }^{\circ}$ que haja uma revisão a fim de que seja estabelecido um eficiente sistema de sanções para os maus aplicadores dos dinheiros públicos e,

2..$^{\circ}$ que se dê elasticidade ao Tribunal de Contas para que êste possa estar presente onde se apliquem dinheiros públicos para que possa avaliar como são aplicados.

(1) I Congresso dos Tribunais de Contas do Brasil. São Paulo, de 20 a 27 de abril de 1958. 